\title{
Optimasi simbiosis cendawan mikoriza arbuskula Acaulospora tuberculata dan Gigaspora margarita pada bibit kelapa sawit di tanah masam
}

\author{
Optimizing arbuscular mycorrhizal fungi symbiosis Acaulospora tuberculata
} and Gigaspora margarita with oil palm seedling in acid soil)

\section{Happy WIDIASTUTI ${ }^{1)}$, Edi GUHARDJA ${ }^{2)}$, Nampiah SOEKARNO ${ }^{2)}$, L. K. DARUSMAN ${ }^{2)}$, Didiek Hadjar GOENADI ${ }^{1)} \&$ Sally SMITH $^{3)}$}

1) Unit Penelitian Bioteknologi Perkebunan, Bogor 16151, Indonesia

2) Fakultas Matematika dan Ilmu Pengetahuan Alam, Institut Pertanian Bogor, Bogor, Indonesia

3) Soil and Land Systems, School of Earth and Environmental Sciences, Adelaide University,

\section{Australia}

\section{Summary}

AM fungal symbiosis increase the uptake of $P$ in oil palm seedlings. However the optimum condition of symbiosis has to be determined to get higher benefit of AM fungal symbiosis. Optimization of the symbiosis Acaulospora tuberculata and Gigaspora margarita with oil palm seedling in acid soil was determined. An experiment was conducted in polybag sized $40 x$ $60 \mathrm{~cm}$ contained sterilized Cikopomayak soil. Three factors studied were AM fungal species (A. tuberculata, G. margarita), inoculant dose $(0.0 ; 12.5 ; 25.0 ;$ and $37.5 \% \mathrm{w} / \mathrm{w})$, and fertilizer rate $(0 ; 25 ; 50$; and $100 \%$ recommended dose) and each treatment replicated three times. The result showed that optimum growth reached on the inoculant addition of $36 \%(w / w)$ in the form of infected roots, hypha, and spores and fertilizer dose of $25 \%$ for A. tuberculata, while for G. margarita was $40 \%(w / w)$ inoculant and $26 \%$ fertilizer. Efectivity of fertilizer and $P$ uptake of oil palm seedling were significantly increased with AM fungi inoculation. P uptake of oil palm seedling inoculated with A. tuberculata increase.

[Key words: Elaeis guineensis Jacq., arbuscularmycorrhizal fungi, fertilizer dose, oil-palm seedling, Acaulospora tuberculata, Gigaspora margarita]

\section{Ringkasan}

Simbiosis cendawan mikoriza arbuskula (CMA) dapat meningkatkan serapan $\mathrm{P}$ pada pembibitan kelapa sawit. Namun, untuk mendapatkan keuntungan simbiosis yang tinggi perlu diketahui kondisi optimum simbiosis. Simbiosis CMA dengan tanaman sangat dipengaruhi tingkat hara dan dosis inokulum. Percobaan dilakukan dalam polibag berukuran 40 x $60 \mathrm{~cm}$ berisi tanah Cikopomayak steril. Tiga faktor yang diuji ialah spesies CMA (A. tuberculata, G. margarita), dosis inokulum campuran $(0,0 ; 12,5 ; 25,0 ;$ dan $37,5 \% \mathrm{~b} / \mathrm{b})$, dosis pupuk $(0 ; 25 ; 50$; dan $100 \%$ dosis rekomendasi) dan masing masing perlakuan diulang tiga kali. Hasil percobaan menunjukkan bahwa pertumbuhan optimum dicapai pada pemberian inokulum berupa akar terinfeksi, hifa, dan spora $36 \%$ (b/b) dan pupuk $25 \%$ untuk A. tuberculata, sedangkan untuk G. margarita ialah $40 \%$ (b/b) inokulum dan pupuk $26 \%$. Keefektifan pupuk dan serapan $\mathrm{P}$ meningkat secara nyata dengan inokulasi CMA. 


\section{H. Widiastuti et al.}

\section{Pendahuluan}

Tanah masam didefinisikan sebagai tanah yang mengandung konsentrasi relatif $\mathrm{H}^{+}$yang tinggi. Pada $\mathrm{pH}$ di bawah tiga, $\mathrm{H}^{+}$ menjadi toksik sedangkan pada $\mathrm{pH}$ di bawah lima terjadi toksisitas $\mathrm{Al}$, defisiensi $\mathrm{Ca}, \mathrm{Mg}$, dan K (Marschner, 1991). Clark (1997) mengemukakan bahwa toleransi dan kemampuan tanaman tumbuh pada tanah masam kemungkinan disebabkan simbiosis dengan CMA. Cumming \& Ning (2003) mengemukakan bahwa simbiosis CMA dengan Andropogon virginicus, L. berperan penting dalam resistensi spesies ini terhadap Al. Pengaruh ini terutama terlihat pada serapan hara $\mathrm{P}$ walaupun kolonisasi CMA juga dikenal dapat meningkatkan serapan $\mathrm{Cu}$, dan $\mathrm{Zn}$. Selain itu, CMA mereduksi akumulasi elemen lain seperti $\mathrm{Al}, \mathrm{Fe}$, dan Mn yang menjadi masalah pada tanah masam (Cumming \& Ning, 2003). Smith et al. (2003) mengemukakan bahwa pada interaksi yang optimum, simbiosis CMA dapat menyediakan jalur dominan untuk penyediaan $\mathrm{P}$ tanaman. Selain itu, kondisi optimum bagi CMA yang diintroduksi dapat meningkatkan keefektifan dan kemampuan bersaing dengan CMA alami.

Kelapa sawit adalah tanaman yang secara alami bersimbiosis dengan CMA (Widiastuti \& Kramadibrata, 1993). Inokulasi CMA pada kelapa sawit dapat meningkatkan efisiensi pemupukan (Blal et al., 1990; Widiastuti et al., 1998), pertumbuhan dan serapan hara (Widiastuti \& Tahardi, 1993), dan meningkatkan daya tumbuh tanaman asal kultur in vitro (Schultz et al., 1999). Namun, keefektifan simbiosis secara maksimal seringkali bervariasi. Oleh karena itu, untuk mendapatkan hasil yang konsisten perlu dilakukan optimasi simbiosis antara CMA dan bibit kelapa sawit. Beberapa hal yang mempengaruhi simbiosis
CMA ialah dosis inokulum dan pupuk. Dosis inokulum berpengaruh terhadap keefektifan inokulasi. Dibandingkan dengan spora sebagai inokulum, propagul campuran berupa spora, akar terinfeksi dan hifa eksternal dapat menginfeksi dalam waktu yang lebih cepat. Penelitian ini bertujuan menetapkan dosis optimum $A$. tuberculata dan G. margarita serta pupuk untuk mendapatkan simbiosis yang optimum pada bibit kelapa sawit di tanah masam.

\section{Bahan dan Metode}

Bahan tanam yang digunakan berupa kecambah kelapa sawit (DxP) berasal dari Pusat Penelitian Kelapa Sawit, Medan, dan tanah steril sebagai medium tanam berasal dari Cikopomayak. Sterilisasi tanah dilakukan dengan oven $110^{\circ} \mathrm{C}$ selama tiga kali dengan selang waktu satu malam. Karakteristik tanah disajikan dalam Tabel 1. Sebelum digunakan sebagai bahan tanam, kecambah kelapa sawit ditumbuhkan dalam bak plastik berisi pasir steril selama dua bulan. Percobaan dilakukan di polibag berukuran 40x $60 \mathrm{~cm}$ berisi $13 \mathrm{~kg}$ tanah steril.

A. tuberculata merupakan koleksi Unit Penelitian Bioteknologi Perkebunan, Bogor, berasal dari kebun kelapa sawit di Kertajaya, Lebak, Jawa Barat sedangkan G. margarita adalah koleksi Pusat Penelitian Kopi dan Kakao Jember yang berasal dari rizosfer kedelai. Inokulum CMA merupakan hasil perbanyakan dengan sistem kultur pot menggunakan Pueraria phaseoloides sebagai tanaman inang untuk $A$. tuberculata sedangkan $G$. margarita diperbanyak menggunakan inang jagung. Inokulum berupa propagul campuran terdiri dari spora, akar terinfeksi, dan hifa. Persentase kolonisasi inokulum lebih dari $75 \%$ dan 
Optimasi simbiosis cendawan mikoriza arbuskula...

Tabel 1. Karakteristik tanah yang digunakan sebagai medium tanam.

Table 1. Characteristic of soil used as growth medium in experiment.

\begin{tabular}{lcl}
\hline Parameter (Parameter) & Nilai (Value) & Katagori (Level) \\
\hline $\mathrm{pH} \mathrm{H}_{2} \mathrm{O}$ & 4,10 & sangat masam ( very acidity) \\
$\mathrm{C}(\%)$ & 1,96 & rendah $($ low $)$ \\
$\mathrm{N}(\%)$ & 0,14 & rendah $($ low $)$ \\
$\mathrm{P}$ tersedia $($ P available) $(\mathrm{ppm})$ & 13,55 & sedang $($ medium) \\
$\mathrm{P}_{2} \mathrm{O}_{5} \mathrm{HCl} 25 \%(\%)$ & 0,04 & sedang $($ medium) \\
$\mathrm{K}_{2} \mathrm{O} \mathrm{HCl} 25 \%(\%)$ & 0,01 & rendah $($ low $)$ \\
$\mathrm{CaO}(\%)$ & 0,08 & \\
$\mathrm{MgO}(\%)$ & 0,01 & \\
$\mathrm{Aluminum}$ dapat ditukar & 13,80 & \\
(Exchangable Allumunium) (Aldd) & & \\
(me 100 g-1tanah (soil) & & \\
\hline
\end{tabular}

kerapatan 3 spora per gram inokulum. Penyiraman tanaman dilakukan menggunakan air ledeng pada pagi hari sesuai kebutuhan tanaman. Inokulasi dilakukan pada saat tanam dengan mencampur inokulum dengan medium tanah. Tanaman dipanen setelah berumur 8 bulan. Percobaan dilakukan untuk menguji 32 perlakuan yang merupakan kombinasi tiga faktor yaitu spesies CMA (A. tuberculata dan $G$. margarita), dosis mikoriza $(0 ; 12,5 ; 25$; dan $37,5 \% \mathrm{~b} / \mathrm{b})$ dan dosis pupuk $(0 ; 25 ; 50$; dan $100 \%$ dosis rekomendasi (Lubis, 1992). Rancangan percobaan yang digunakan ialah rancangan acak lengkap pola faktorial dengan ulangan tiga kali.

\section{Hasil dan Pembahasan}

Analisis statistik menunjukkan interaksi yang nyata antara dosis inokulum CMA dan dosis pupuk. Pengamatan pada bobot kering bibit kelapa sawit menunjukkan bahwa bibit yang tidak diinokulasi CMA meningkat secara nyata, demikian pula pada pemupukan $25 \%$ (Tabel 2). Walaupun demikian diperlukan dosis CMA yang lebih tinggi dengan bertambahnya dosis pemupuk- an. Pada perlakuan tanpa pemupukan diperlukan dosis mikoriza $12,5 \%$ sedangkan pada perlakuan dengan pemupukan $25 \%$ diperlukan dosis mikoriza 25\% untuk mendapatkan respons inokulasi CMA yang nyata. Respons bibit terhadap inokulasi pada dosis pemupukan yang lebih tinggi tidak konsisten. Hasil yang diperoleh menunjukkan bahwa inokulasi CMA dapat mengurangi dosis pupuk. Pada perlakuan tanpa inokulasi, pertumbuhan maksimum dicapai dengan dosis pupuk 100\% sedangkan dengan inokulasi pertumbuhan maksimum dapat dicapai dengan dosis pupuk $25-50 \%$.

Hubungan antara dosis mikoriza (D), dosis pupuk $(\mathrm{P})$, dan bobot kering bibit yang diinokulasi $A$. tuberculata $\left(\mathrm{Y}_{\mathrm{At}}\right)$ dapat dinyatakan dengan persamaan $\mathrm{Y}_{\mathrm{At}}=22,02$ $+1,63 \mathrm{D}+0,47 \mathrm{P}-0,015 \mathrm{D}^{2}-0,005 \mathrm{PD}-0,0029 \mathrm{P}^{2}$ (Gambar 1a). Pertumbuhan optimum dicapai dengan beberapa kombinasi dosis mikoriza dan dosis pupuk pada masing-masing bobot kering yang diinginkan (Gambar 1b). Dosis pupuk $25 \%$ yang disertai pemberian inokulum mikoriza sebanyak $36 \%(\mathrm{~b} / \mathrm{b})$, diduga dapat menghasilkan bobot kering tanaman optimum yaitu sebesar $65 \mathrm{~g}$. 


\section{H. Widiastuti et al.}

Tabel 2. Pengaruh dosis CMA dan dosis pupuk terhadap bobot kering bibit kelapa sawit umur delapan bulan.

Table 2. Effect of AM fungal dose and fertilizer on dry weight of eight months oil palm seedling.

\begin{tabular}{ccccc}
\hline \multirow{2}{*}{$\begin{array}{c}\text { Dosis CMA } \\
\text { AM fungal dose } \\
(\% \mathrm{w} / \mathrm{w})\end{array}$} & 0 & 25 & 50 & 100 \\
\cline { 2 - 5 } & $\left.\left.20,60 \mathrm{~b}^{l}\right) \mathrm{q}^{2}\right)$ & $25,30 \mathrm{c} \mathrm{q}$ & $34,20 \mathrm{a} \mathrm{q}$ & $51,60 \mathrm{a} \mathrm{p}$ \\
& \multicolumn{5}{c}{$\begin{array}{c}\text { Dosis pupuk, \% rekomendasi } \\
\text { (Fertilizer dose, \% recommendation })\end{array}$} \\
12,00 & $44,40 \mathrm{a} \mathrm{pq}$ & $44,80 \mathrm{~b} \mathrm{pq}$ & $52,70 \mathrm{a} \mathrm{p}$ & $30,50 \mathrm{~b} \mathrm{q}$ \\
25,00 & $39,80 \mathrm{a} \mathrm{q}$ & $66,40 \mathrm{a} \mathrm{p}$ & $45,60 \mathrm{a} \mathrm{pq}$ & $57,50 \mathrm{a} \mathrm{p}$ \\
37,50 & $40,40 \mathrm{a} \mathrm{q}$ & $72,10 \mathrm{a} \mathrm{p}$ & $50,20 \mathrm{a} \mathrm{q}$ & $68,50 \mathrm{a} \mathrm{p}$ \\
\hline
\end{tabular}

Angka dalam kolom ${ }^{1)}$ atau baris $^{2)}$ yang sama pada masing-masing kelompok yang diikuti huruf yang sama tidak berbeda nyata berdasarkan uji jarak berganda Duncan , $\mathrm{P}<0,05$.

Figure in each column ${ }^{1)}$ or row $^{2)}$ in each group followed by same letter is not significantly different according to Duncan Multiple Range Test, $P<0.05$.

Pada bibit yang diinokulasi G. margarita, hubungan antara dosis mikoriza (D), dosis pupuk (P) dan bobot kering $\left(\mathrm{Y}_{\mathrm{Gm}}\right)$ dapat dinyatakan dengan persamaan $\mathrm{Y}_{\mathrm{Gm}}=26,14+$ $0,37 \mathrm{D}+0,26 \mathrm{P}+0,001 \mathrm{D}^{2}+0,003 \mathrm{PD}-$ $0,001 \mathrm{P}^{2} \quad$ (Gambar 2a). Plot kontur menunjukkan bahwa pertumbuhan optimum dapat dicapai dengan beberapa kombinasi dosis pupuk dan dosis mikoriza (Gambar 2b). Pemberian dosis pupuk 26\% yang disertai inokulum mikoriza sebanyak $40 \%$ (b/b), diharapkan dapat meningkatkan bobot kering tanaman hingga $50 \mathrm{~g}$.

Tampak bahwa masing-masing spesies CMA memerlukan kondisi optimum yang berbeda untuk mendapatkan simbiosis fungsional. Dengan demikian untuk mencapai pertumbuhan optimum diperlukan dosis pupuk dan dosis mikoriza yang lebih tinggi pada inokulasi $G$. margarita dibandingkan dengan inokulasi $A$. tuberculata. Hasil ini menunjukkan bahwa inokulasi A. tuberculata lebih efektif dibandingkan dengan inokulasi $G$. margarita khususnya dalam meningkatkan pertumbuhan bibit kelapa sawit. Kondisi optimum simbiosis A. tuberculata dan $G$. margarita dengan kelapa sawit dapat dicapai dengan pemupukan yang rendah yaitu sekitar $25 \%$ dosis rekomendasi. Mosse (1973) melaporkan pengaruh yang merugikan tingkat $\mathrm{P}$ tanah yang tinggi pada simbiosis CMA, terutama disebabkan oleh konsentrasi $\mathrm{P}$ yang tinggi di akar. Tingginya $\mathrm{P}$ menghambat CMA secara langsung dengan menekan perkecambahan spora dan pertumbuhan hifa dari spora yang berkecambah (Miranda \& Harris, 1994; Nagahashi et al., 1996). P mengatur ekspresi gen pada cendawan seperti fosfatase (Kaffman et al., 1994), transporter P (Versaw, 1995), dan protein yang berkaitan dengan metabolisme polifosfat (Ogawa et al., 2000). P transporter diregulasi oleh ketersediaan $\mathrm{P}$ dimedium eksternal dan juga status akar pada tanaman inang (Olsson et al., 2002).

Menurut Olsson et al. (2002) respons langsung hifa eksternal terhadap konsentrasi $\mathrm{P}$ dimedium rendah. Pengaruh yang dijumpai nampaknya berkaitan dengan 
Optimasi simbiosis cendawan mikoriza arbuskula...

A

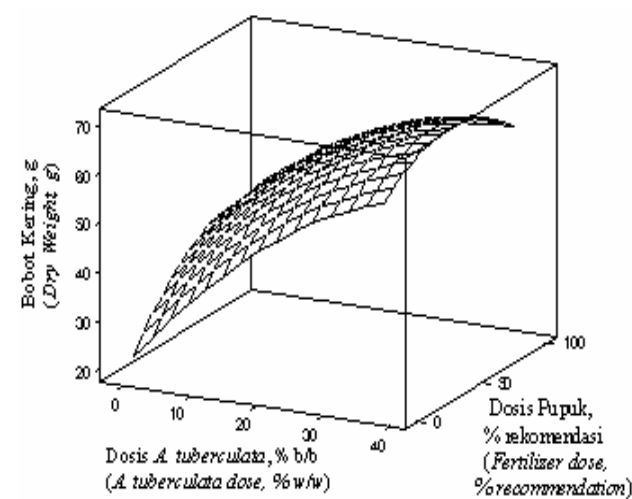

B

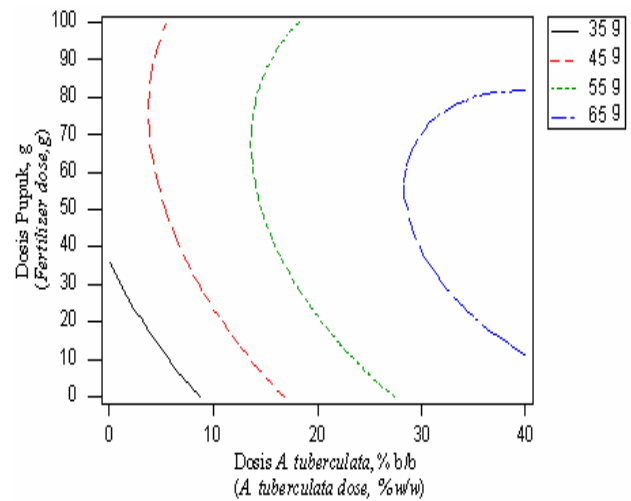

Gambar 1. Hubungan (A) dan plot kontur (B) antara dosis mikoriza, dosis pupuk, dan bobot kering bibit kelapa sawit yang diinokulasi $A$. tuberculata pada umur delapan bulan.

Figure 1. Relationship(A) and contour plot (B) between AM fungal inoculant dose, fertilizer dose, and dry weight of oil palm seedling inoculated with A. tuberculata eight months old.

A

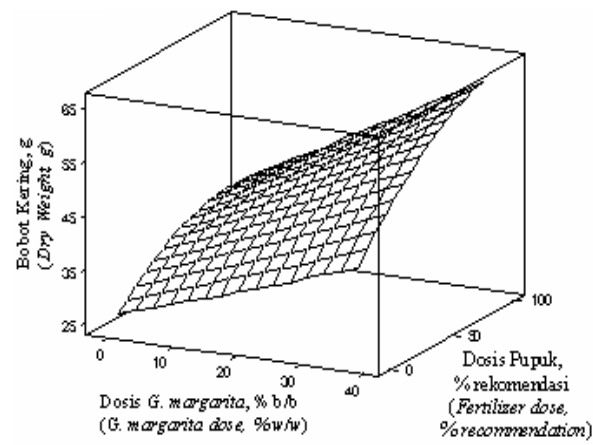

\section{B}

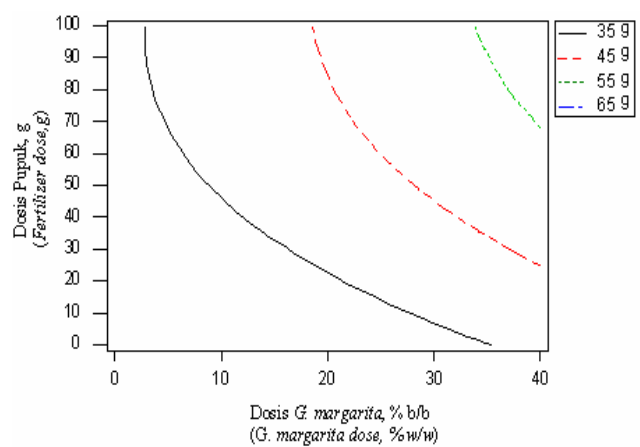

Gambar 2. Hubungan (A) dan plot kontur (B) antara dosis mikoriza, dosis pupuk, dan bobot kering bibit kelapa sawit yang diinokulasi $G$. margarita pada umur delapan bulan.

Figure 2. Relationship (A) and contour plot (B) between AM fungal inoculant dose, fertilizer dose, and dry weight of oil palm seedling inoculated with G. margarita eight months old. 


\section{H. Widiastuti et al.}

peningkatan ketersediaan $\mathrm{P}$ bagi akar tanaman. Hasil ini menunjukkan bahwa inokulasi CMA dapat mengurangi konsumsi pupuk dan meningkatkan efisiensinya. Namun, pupuk tetap diperlukan untuk mendapatkan simbiosis yang optimum.

Berdasarkan persamaan yang menjelaskan hubungan antara dosis inokulum dan dosis pupuk terhadap bobot kering bibit diperkirakan pertumbuhan maksimum bibit (69,08 g) yang diinokulasi A. tuberculata tercapai pada pemberian pupuk $42 \%$ dan inokulum mikoriza $46 \%$. Sedangkan untuk G. margarita dosis pupuk dan mikoriza untuk mencapai pertumbuhan maksimum tidak dapat ditetapkan pada percobaan ini. Bagaimanapun, dari plot kontur yang diperoleh ditunjukkan bahwa pertumbuhan maksimum yang dapat dicapai oleh bibit yang diinokulasi $A$. tuberculata lebih tinggi dibandingkan dengan bibit yang diinokulasi G. margarita. Perbedaan respons tumbuh disebabkan adaptasi $A$. tuberculata lebih tinggi pada kondisi percobaan dibandingkan dengan G. margarita. Hasil penelitian yang diperoleh berbeda dengan hasil yang dilaporkan Widiastuti et al. (1998) yang melaporkan bahwa G. margarita lebih efektif dibandingkan dengan $A$. tuberculata. Walaupun demikian terdapat perbedaan sifat kimia tanah yang digunakan pada kedua percobaan tersebut. Widiastuti et al. (1998) menggunakan tanah Sanghyangdamar yang mempunyai kandungan $\mathrm{P}$ tersedia sangat tinggi dan $\mathrm{P}$ total sedang, serta Aldd lebih rendah, demikian pula tingkat kemasaman tanah. Perbedaan ini menunjukkan adanya perbedaan keefektifan satu spesies CMA pada satu lokasi.

Pengamatan serapan hara $\mathrm{P}$ menunjukkan kecenderungan yang sama dengan pertumbuhan bibit. Pada perlakuan tanpa pemupukan, inokulasi CMA dapat meningkatkan serapan $\mathrm{P}$ secara nyata (Tabel 3).

Tabel 3. Pengaruh dosis CMA dan dosis pupuk terhadap serapan hara P bibit kelapa sawit umur delapan bulan.

Table 3. Effect of AM fungal dose and fertilizer on P uptake of eight months oil palm seedling.

\begin{tabular}{|c|c|c|c|c|}
\hline \multirow{2}{*}{$\begin{array}{l}\text { Dosis CMA } \\
\text { AM fungal dose } \\
\quad(\% w / w)\end{array}$} & \multicolumn{4}{|c|}{$\begin{array}{c}\text { Dosis pupuk, \% rekomendasi } \\
\text { Fertilizer dose, \% recommendation }\end{array}$} \\
\hline & 0 & 25 & 50 & 100 \\
\hline 0,00 & $4,70 b^{1)} q^{2)}$ & $5,30 \mathrm{~b} \mathrm{q}$ & 8,30 a $\mathrm{q}$ & 13,60 a $p$ \\
\hline 12,50 & 9,80 a q & 11,10 a $p$ & $11,10 \mathrm{a} p$ & $6,90 \mathrm{~b} \mathrm{q}$ \\
\hline 25,00 & 9,40 a q & 12,60 a $p$ & 9,60 a $p$ & $10,60 \mathrm{ab} p$ \\
\hline 37,50 & 9,40 a q & 14,70 a $p$ & 11,20 a p & 14,60 a p \\
\hline
\end{tabular}

Angka dalam kolom ${ }^{1)}$ atau baris $^{2)}$ yang sama pada masing-masing kelompok yang diikuti huruf yang sama tidak berbeda nyata berdasarkan uji jarak berganda Duncan , $\mathrm{P}<0,05$.

Figure in each column ${ }^{1)}$ or row $^{2)}$ in each group followed by same letter is not significantly different according to Duncan Multiple Range Test, $P<0.05$. 
Optimasi simbiosis cendawan mikoriza arbuskula...

Demikian pula pada pemupukan $25 \%$, sedangkan pada dosis pemupukan yang lebih tinggi pengaruh inokulasi tidak nampak. Pada perlakuan tanpa inokulasi, serapan $\mathrm{P}$ maksimum dicapai dengan pemupukan $100 \%$ sedangkan dengan inokulasi CMA dosis pupuk dapat dikurangi sebesar 25-50\%. Efisiensi serapan hara $\mathrm{P}$ tanaman bermikoriza dipengaruhi oleh tiga tahap yaitu serapan hara oleh miselia CMA dari tanah, translokasi hara dalam hifa ke struktur intraradikal CMA dalam akar dan transfer hara dari CMA ke sel tanaman melewati interfase.

Pada ketersediaan hara yang rendah hifa dapat menyerap hara dari tanah yang tidak dapat diserap oleh akar sehingga pengaruh CMA terhadap serapan hara tinggi. Namun pada $\mathrm{P}$ yang cukup, akar tanaman dapat berperan sebagai organ penyerap hara sehingga tanaman mengakumulasi $\mathrm{P}$ dalam jumlah yang tinggi. Pada keadaan ini CMA tetap mendapatkan senyawa $\mathrm{C}$ dari tanaman sehingga mempengaruhi metabolisme tanaman. Serapan hara oleh CMA tidak menyebabkan respons pertumbuhan yang positif karena faktor lain seperti akuisisi C menjadi pembatas pertumbuhan tanaman sehingga pada keaadan $\mathrm{P}$ yang sangat tinggi bahkan dapat menyebabkan respons yang negatif terhadap kolonisasi CMA (Smith \& Read, 1997).

\section{Kesimpulan}

Simbiosis optimum $A$. tuberculata dengan kelapa sawit dapat dicapai dengan $36 \%$ (b/b) inokulum dan 25\% dosis rekomendasi pupuk. Sedangkan untuk G. margarita, dosis optimum adalah $40 \%$ (b/b) inokulum dan $26 \%$ dosis rekomendasi pupuk. Selain dapat meningkatkan pertumbuhan bibit, dosis optimum juga dapat meningkatkan serapan P bibit.

\section{Daftar Pustaka}

Blal, B., C. Morel, V. Gianinazzi-Pearson, J.C. Fardeau \& S. Gianinazzi (1990). Influence of vesicular-arbuscular mycorrhizae on phosphate fertilizer efficiency in two tropical acid soils planted with micropropagated oil palm (Elaeis guineensis Jacq). Biol. Fertil. Soils, 9, 43-48.

Clark, R.B. (1997). Arbuscular mycorrhizal adaptation, spore germination, root colonization, and host plant growth and mineral acquisition at low $\mathrm{pH}$. Plant Soil, 192, 15-22.

Cumming J.R. \& J. Ning (2003). Arbuscular mycorrhizal fungi enhance aluminium resistance of broomsedge (Andropogon virginicus, L.) J. Exp. Bot., 54, $1447-$ 1459.

Kaffman, A., I. Herskowitz, R. Tijan \& E.K. O'shea (1994). Phosphorilation of the transcription factor $\mathrm{PHO} 4$ by a cyclin-CDK complex, PHO80-PHO85. Science, 263, 1153-1156.

Marschner, H. (1991). Mineral Nutrition of Higher Plants. San Diego, Acad. Press.

Miranda, J.C.C. \& P.J. Harris (1994). Effects of soil phosphorus on spore germination and hyphal growth of arbuscular mycorrhizal fungi. New Phytol., 128, 103-108.

Mosse, B. (1973). Advances in the study of vesicular arbuscular mycorrhiza. Ann. Rev. Phytopathol., 11, 171-196.

Nagahashi, G., D.D. Douds Jr. \& G.D. Abney (1996). Phosphorus amendment inhibits hyphal branching of the VAM fungus Gigaspora margarita directly and indirectly through its effect 


\section{H. Widiastuti et al.}

on root exudation Mycorrhiza, 6, 403408.

Ogawa, N., de Risi \& J. P.O. Brown (2000). New components of a system for phosphate accumulation and polyphosphate metabolism in Saccharomyces cerevisiae revealed by genomic expression analysis. Mol. Biol. Cell, 11, 4309-4321.

Olsson, P.A., I. van Aarie, W.G. Allaway, A. Ashford \& H. Rouhier (2002). Phosphorus effects on metabolic processes in monoxenix arbuscular mycorrhiza cultures. Plant Physiol., 130, 1162-1171.

Schultz, C., Subronto, S. Latif, A.M. Moawad \& P.L.G. Vlek (1999). Peranan mikoriza vesikuler-arbuskuler (MVA)dalam meningkatkan penyesuaian diri planlet kelapa sawit terhadap kondisi lingkungan tumbuh alami. $J$. Penelitian Kelapa Sawit, 7, 145-156.

Smith, S.E. \& D.J. Read (1997). Vesiculararbuscular mycorrhizas: Growth and carbon economy of VA mycorrhizal plants. In Mycorrhizal Symbiosis. $\quad 2^{\text {nd }}$ ed. New York, Acad. Press. p.105-125.
Smith, S.E., F.A. Smith \& I. Jacobsen (2003). Mycorrhizal fungi can dominate phosphate supply to plants irrespective of growth responses. Plant Physiol., 133, 16-20.

Versaw, W.K. (1995). A phosphaterepresible, high affinity phosphate permease is encode by the pho5+ gene of Neurospora crassa. Gene, 153, $135-$ 139.

Widiastuti, H. \& J.S. Tahardi (1993). Effect of vesicular-arbuscular mycorrhizal inoculation on the growth and nutrient uptake of micropropagated oil palm. Menara Perkebunan, 61(3), 56-60.

Widiastuti, H. \& K. Kramadibrata (1993). Identifikasi jamur mikoriza bervisikula arbuskula di beberapa kebun kelapa sawit di Jawa Barat. Menara Perkebunan, 61(1), 13-19.

Widiastuti, H., T.W. Darmono \& D.H. Goenadi (1998). Respons bibit kelapa sawit terhadap inokulasi beberapa cendawan AM pada beberapa tingkat pemupukan. Menara Perkebunan, 66(2), 36-46 